\title{
Education System in Financial Life Skills (FLS) Training - USAID YEP
}

\author{
Illa Susanti* \\ Prodi Pendidikan Masyarakat \\ Universitas Pendidikan Indonesia \\ Bandung, Indonesia
}

\begin{abstract}
The Financial Life Skill (FLS) Training is conducted by USAID's YEP is an effort to prepare young people to provide life skills and financial literacy so they can manage finances well and not make financial mistakes. This qualitative approach will evaluate the FLS training program with a system approach that will describe the components of the FLS training as system: raw input, instrument input, process, environment input and output. It will be discussed regarding learning evaluations both before, during and after training. The results of the study showed that FLS training was designed with a training cycle that was in line with the concept of adult education. The strengths of this program are the comprehensive curriculum and modules, accompanied by a well-managed training process and IT system support for monitoring and evaluation. While the evaluation of learning is carried out before, during and after the training to ensure the training objectives can be achieved.
\end{abstract}

Keywords-finansial lifeskill, finansial training, finansial training evaluation

\section{INTRODUCTION}

The results of a survey conducted by the Financial Services Authority (OJK) in 2016 showed that the Indonesian society's Financial Literacy Index was still very low at 29.7\% [1]. To increase financial literacy, financial education is necessary, especially for youth [2].

Financial management skills will greatly affect the lives and welfare of individuals and families so that governments around the world consider financial education to be very important to increase financial literacy [3]. According to Lusardi financial literacy is the skill of the 21 st century, but it seems that the level of public financial literacy is still very low both globally and in Indonesia $[1,4]$. Low financial management skills are found at various levels of society, including those with low, middle and high income.

Cummins states that a person's ability to manage finances is one of the important factors for achieving success in life, so that knowledge of good and correct financial management is important for each individual [5].

Good financial management is measured by five components [6] which consist of being able to spend money as needed, paying monthly obligations on time, planning finances for future needs, saving savings, and setting aside funds for yourself and your family. This ability is part of financial literacy which includes calculation skills, understanding of basic finance, and attitudes towards financial decisions [7].

Good financial literacy education is the only way to build life skills, especially in financial literacy [8]. Prawitz and Cohart stated that financial education programs have succeeded in increasing financial literacy [9].

Like Australia, around the world most financial literacy programs and curricula follow what Lucey et al., describe as a conventional approach to Financial Literacy Education and now widely available to all nationals through compulsory schooling and / or other educational opportunities in countries such as Australia, Canada and the United States [10].

One of financial training in Indonesai is the Financial Life Skills (FLS) program for youth development by the United States Agency for International Development (USAID) through the Youth Economic Participation (YEP) project.

The FLS program is a program to empower Indonesian youth from economically disadvantaged and vulnerable groups (Poor and Vulnarable - P\&V). This training is designed to equip participants with soft skills related to work readiness such as cooperation, communication, punctuality, etc. and financial management skills such as determining financial goals, making budgets, avoiding fraud, etc.

FLS training has been running since 2017 and is implemented in various regions in Indonesia with the main target of the younger generation. USAID YEP strives to keep more youth participating in the FLS training program. In the FLS training held at Universitas Merdeka Malang with 28 participants, Siswati [11] shows that this training provides significant results and Zulbetti [12] states that participant FLS training satisfaction is very high.

Previous research has focused more on measuring the output of financial training results. This paper aims to explore further the various components that are interconnected as a system of public education that is raw input, instrument input, process, environment input and output. It will be discussed 
regarding learning evaluations both before, during and after training.

\section{METHODS}

This article implemented a descriptive qualitative approach that relied on triangulation of data generated from three methods: interview, participant to observation, and review of organizational records (document records). Interviews were conducted with trainers and FLS training participants. Observations were made on the implementation of FLS training of trainers (FLS-TOT) for basic trainers in Solo West Java and FLS training of youth (FLS ToY) which was held at STAI Siliwangi Garut, West Java and IAIN Ponorogo, East Java. Document records come from tests and questionnaires distributed to participants at the end of each session and at the end of the training.

\section{A. Program Evaluation}

In an educational perspective, evaluation is defined as the process of collecting data in order to determine the extent, in what terms and to what part of the educational goals that have been achieved [13]. Bloom said that evaluation is a systematic collection of facts to determine whether in reality there have been changes from students and to determine the extent of changes in the students' personality [14].

The main purpose of educational evaluation is psychological needs which include cognitive (intellectual, curiosity, creativity), affective (motivation, feelings, emotions), and psychomotor (actualization, opportunities for activity), didactic or instructional needs as giving education for students to be motivated to advance in achievement and administrates needs [15].

Program evaluation is an effort to collect information about a program, activity, or project. This information is useful to make decisions in improving the program, improving the follow-up program, stopping an activity, or disseminating the ideas underlying a program or activity [16].

The program aspects evaluated as a system consisting components of environmental input, instrumental input, raw input, processes, output, other input, and outcome [16]. This is illustrated in Figure 1.

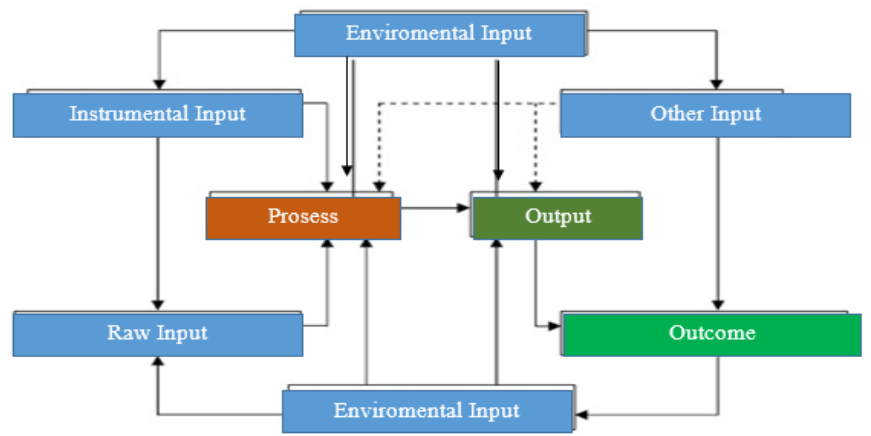

Fig. 1. Functional relationships between components, processes and objectives of the outside school education system [16]

\section{FINDINGS AND DISCUSSION}

\section{A. FLS Training System Evaluation}

To evaluate the FLS program, the author uses an approach by evaluating the elements that exist in the FLS training education system. The system is a unit consisting of the elements that are interrelated and influenced each other in achieving goals.

Based on the review of the FLS training program system, the existing elements can be described as follows (Figure 2).

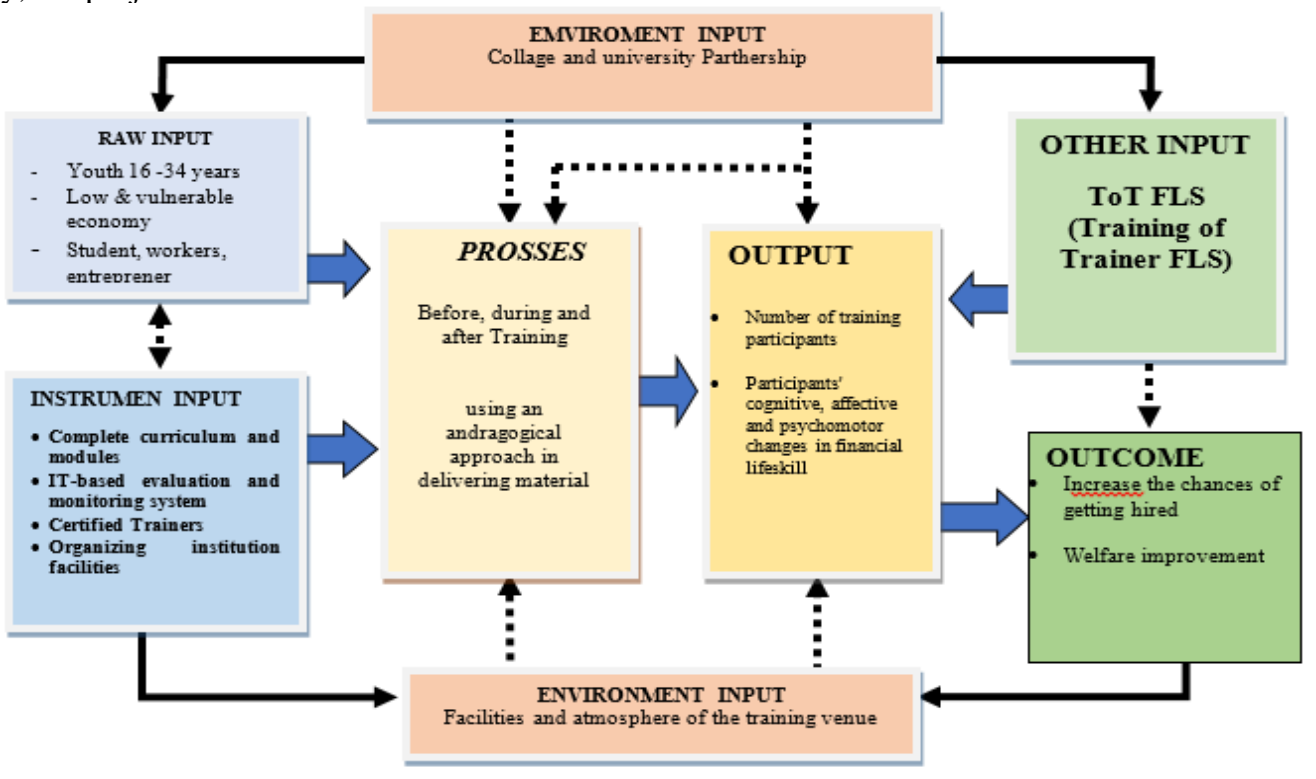

Fig. 2. Design the FLS training as a system. 


\section{B. Raw Input}

The target of participants as raw input in the FLS ToY training is that youth aged 16-35 years are prioritized for the poor and vulnerable with attention to gender balance. The participants can be students, university students, job seekers or already working, including youth with special needs. FLS has no specific criteria in selecting young people to participate in the program. YEP believes that every Indonesian youth needs to be equipped with skills related to job readiness and financial intelligence so that they have a better chance of finding work or opening a business.

The requirements for participating in the FLS training are registering as a participant, being willing to attend the FLS training with a total duration of 24 hours, and being willing to complete an action plan. One training class is attended by $20-$ 24 participants.

\section{Instrumental Input}

1) Curriculum: The most important input is the availability of a curriculum or learning module. The FLS module is divided into 14 materials covering essential and basic life skills, which are indispensable for young people. The module was developed based on the results of the Labor Market Assessment survey conducted by the YEP Project in May to June 2017 in Bandung, Indramayu, Tasikmalaya, and Sukabumi Districts. This module is prepared for educators and trainers from various education and / or training providers to be used as a basic guideline in conducting "Financial-Based Life Skills" training for young people in Indonesia in a systematic and structured manner and meeting the quality standards outlined by the YEP Project (YEP - USAID). The curriculum compiled in the FLS training is very good, it has been tested, and the modules are completely and systematically made. Therefore, they are easy to apply by trainers. The curriculum has met the principles of curriculum preparation, namely the principle of relevance, the principle of effectiveness, the principle of efficiency, the principle of sustainability, the principle of flexibility and the principle of integrity between modules, experiences and activities contained in the curriculum, as well as the linkage between curriculum content and the needs of participants and society.

2) Trainers and team training: The FLS program was developed by a core team responsible for ensuring that USAID's YEP project objectives are met. The module development and preparation of the FLS trainers were carried out by main trainers from both outside and from Indonesia. Standardized training for trainers makes FLS trainers have sufficient capabilities to facilitate training properly. Trainers who had participated in the ToT and implemented training in their respective institutions could increase their capacity to reach the position of master trainer with a process as shown below (Figure 3).

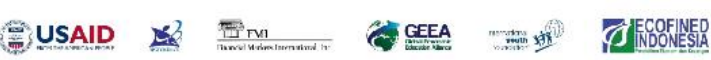 \\ YOUTHWINTHROUGH ECONOMIC PARTICIPATION}
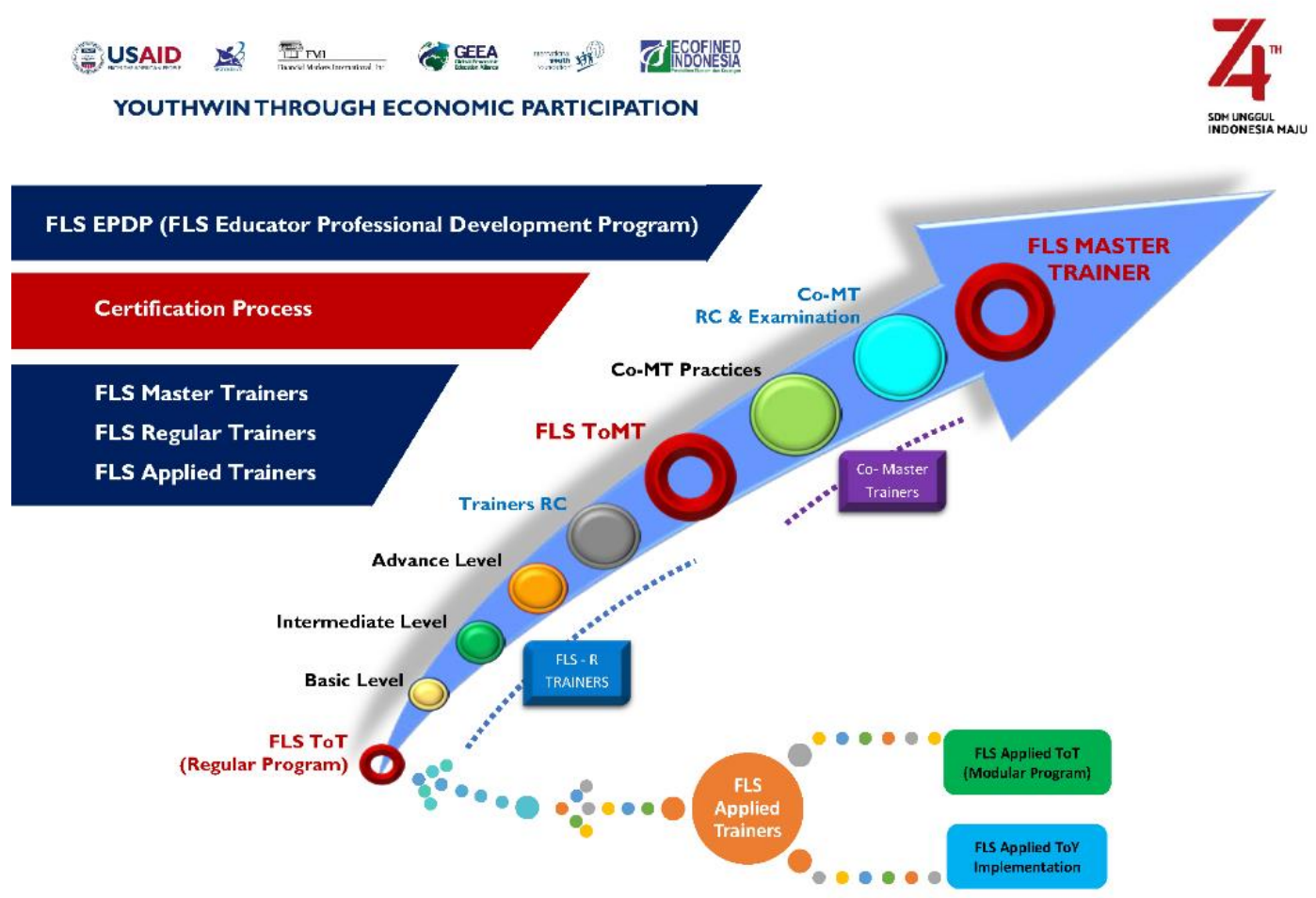

Fig. 3. FLS trainer self-development. 
The FLS ToY training itself is guided by FLS trainers who have participated in the FLS Training of Trainers (ToT) activities. The Lead Trainer is the main person in charge of ensuring the implementation of all processes in the FLS Training, including the application of the MEDS reporting system. Co Trainers have an important role in supporting the proper and efficient implementation of FLS Training. As of February 22, 2019, YEP USAID had organized a ToT of 5 trainings which was attended by 41 institutions and 104 participants and organized 4 times the Modular TOT attended by 12 institutions and 84 participants (as of 18 March 2019).

3) Facilities and infrastructure: Most of the FLS training is implemented at partner institutions which have the responsibility of providing representative training rooms and training support properties. The trainer must make a check list that has been specified in the FLS module before starting training to ensure that all equipment is available.

4) Cost: The training financing scheme is divided into training that is fully funded by YEP, sharing financing between YEP and the organizing institution and independent training where the costs are fully borne by the organizing agency.

5) IT based database: Monitoring, Evaluation, and Database System (MEDS) is an integrated component in the FLS Training Curriculum which is built as a measuring tool. MEDS is important to be applied in order to determine the impact and the effectiveness of the FLS Training Program held for youth, as a portfolio of trainers and partner institutions. The existence of a website that administers FLS training is very helpful for facilitators and program administrators in collecting, administrating, implementing, and evaluating the programs. The data managed through MEDS includes participant biodata, training assessment, pretest, post-test, attendance list, activity reports (name of institution, time, place, lead trainer and co trainer, number of participants, funding and training overview). Meanwhile, the existence of an IT-based monitoring and evaluation system are very helpful for trainers and program managers to obtain and process data for evaluation. In the end, a comprehensive curriculum and modules, accompanied by a well-managed training process and IT system support for monitoring and evaluating make a well-developed FLS training which is able to achieve it goals.

\section{Process}

Each FLS training program has a training cycle that discusses step by step the process of designing and implementing the training program. This is called a cycle because the end result of a training is used as input for improvement plans for further training and to improve the quality of the FLS training program from time to time. The cycle is described as follows (Figure 4).

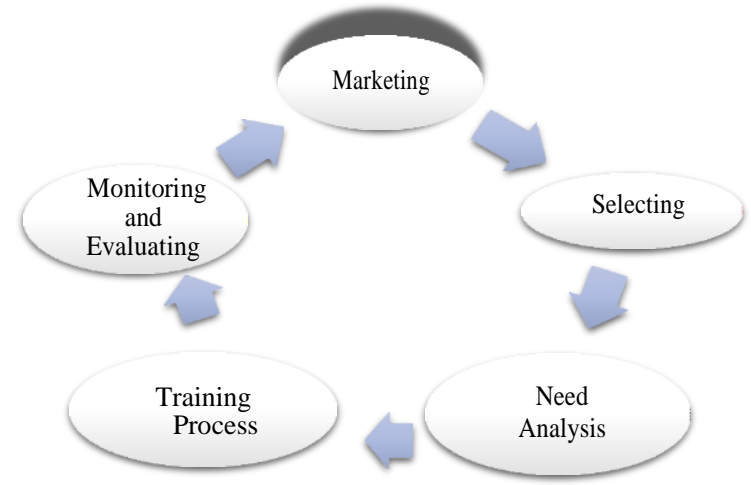

Fig. 4. FLS training cycle.

The cycle of FLS training activities means that this program can always develop and improve itself as a result of feedback from the evaluations implemented. Likewise, with the Training Need Assessment process, which must be implemented by trainers before training, making the program run according to the needs of the participants.

The FLS training program is designed according to the four pillars of education, namely: 1) learning to know, 2) learning to do, 3 ) learning to be, and 4) learning to live together and those are developed in accordance with the principles of non-formal education as stated by Sudjana [16], namely: (1) The principle of need in which educational programs are organized to meet the needs of students; (2) The principle of the relevance to the times; (3) The principle of future insight to prepare participants to enter the world of work; and (4) The principle of lifelong education where participants are equipped with skills to be able to continue to develop themselves and learn independently.

Learning evaluation is before training, during training, and after the completion of the FLS training.

1) Before training: Before starting the training, trainers must doing a Training Needs Assessment (TNA) using a form and questionnaire that participants must fill in, including:

- Background profile, it aims to collect information regarding each FLS participant, including a brief assessment of their social and educational background which can help trainers select and classify potential FLS participants.

- Pre-Assessment, it is to compile a brief assessment of participants' knowledge of the FLS concept.

Based on the results, the TNA trainer made a session plan including determining whether all 14 modules or only a portion would be given to participants. The trainer must also ensure that all the equipment needed for each session is available and prepare a training schedule and adjust it to the time the participants have.

2) During training: FLS training is using the andragogical learning model or adult learning. There are 14 learning modules in this FLS ToY training (See Table 1). All modules 
have been systematically arranged, completed, and measurable. Modules include learning objectives, module outline, important questions, duration, tools needed, learning processes and activities and closings.

TABLE I. LIST OF 14 FLS TOY TRAINING MOdULES

\begin{tabular}{|c|c|c|c|}
\hline No & Title & Duration & Activities \\
\hline 1 & $\begin{array}{l}\text { Introduce to Soft Skillsand } \\
\text { Financial Skills }\end{array}$ & 60 & $\begin{array}{l}\text { - } \begin{array}{l}\text { Brainstorm training } \\
\text { objectives }\end{array} \\
\text { - } \text { Discussion } \\
\text { - } \text { True False Card games }\end{array}$ \\
\hline 2. & Build Self-confidence & $60-90$ & $\begin{array}{l}\text { - } \text { Case Study } \\
\text { - } \quad \text { Self-confidence } \\
\text { worksheets } \\
\text { - } \quad \text { True False Card game }\end{array}$ \\
\hline 3. & Build Human Resources & 90 & $\begin{array}{l}\text { - Personal SWOT analysis } \\
\text { work sheets } \\
\text { - Division worksheet } \\
\text { - The List of Salary }\end{array}$ \\
\hline 4. & $\begin{array}{l}\text { Being a Personally } \\
\text { Responsible: Personal and } \\
\text { Financial }\end{array}$ & 90 & $\begin{array}{l}\text { - Group activity to assess a } \\
\text { case }\end{array}$ \\
\hline 5. & $\begin{array}{l}\text { Critical thinking in } \\
\text { problem solving }\end{array}$ & 90 & $\begin{array}{l}\text { - Assessment worksheets of } \\
\text { PACED } \\
\text { - Case Study } \\
\text { - Opportunity cost } \\
\text { illustration }\end{array}$ \\
\hline 6. & $\begin{array}{l}\text { Setting Life Goals: } \\
\text { Personal and Financial }\end{array}$ & 90 & $\begin{array}{l}\text { - Action plans worksheets } \\
\text { - Networking worksheets }\end{array}$ \\
\hline 7. & $\begin{array}{l}\text { Budgeting and Managing } \\
\text { Finances }\end{array}$ & 90 & $\begin{array}{ll}\text { - } & \text { Choosing product } \\
\text { - } & \text { Creating budget } \\
\text { - } & \text { Creating personal budget }\end{array}$ \\
\hline 8. & $\begin{array}{l}\text { Overcoming the Habit of } \\
\text { Postponing Work }\end{array}$ & 90 & $\begin{array}{l}\text { - } \text { Case Study } \\
\text { - } \quad \text { PITG worksheets }\end{array}$ \\
\hline 9. & Planning for Savings & 90 & $\begin{array}{l}\text { - Determining the time of } \\
\text { benefits and costs } \\
\text { - Rule of } 72 \\
\text { - Illustrating and case study }\end{array}$ \\
\hline 10. & Credit and Loans & 90 & $\begin{array}{ll}\text { - } & \text { Case Study } \\
\text { - } & \text { Game Credit Board } \\
\end{array}$ \\
\hline 11. & Positive Communication & 90 & $\begin{array}{ll}\text { - } & \text { Role playing } \\
\text { - } & \text { Self-introduction } \\
\end{array}$ \\
\hline 12. & $\begin{array}{l}\text { Illegal Investment and } \\
\text { Financing Schemes }\end{array}$ & 90 & $\begin{array}{ll}\text { - } & \text { Role Playing } \\
\text { - } & \text { Match quiz } \\
\text { - } & \text { Even card } \\
\text { - } & \text { Protecting } \\
& \text { worksheets } \\
\end{array}$ \\
\hline 13. & \begin{tabular}{|l|} 
Teamwork \\
Professionalism \\
\end{tabular} & 90 & $\begin{array}{ll}\text { - } & \text { Case Study } \\
\text { - } & \text { Making Crown } \\
\end{array}$ \\
\hline 14. & $\begin{array}{l}\text { Create Action Plans to } \\
\text { Achieve Personal and } \\
\text { Financial Goals }\end{array}$ & & $\begin{array}{l}\text { - The Wealth Game } \\
\text { - Create a Personal Action } \\
\text { Plan }\end{array}$ \\
\hline
\end{tabular}

The learning evaluation are:

- Opening session: to determine the training objectives, expectations, and targets desired by the participants. This session is very important to foster curiosity, readiness to learn and participate and create a comfortable and conducive atmosphere.
- At the end of each session: Write down the points learned in that session

- Daily evaluation: Reflect on the lessons of the day, write down the most WOW points and why. The following day a feedback process was discussed on yesterday's evaluation

Learning evaluation in FLS training is implemented before, during, and after the training takes place. This makes the evaluation of learning outcomes more comprehensive and indirectly helps to achieve the final goal because it is always monitored at each stage of the training.

The learning model approach applies the andragogical system where adult education is applied in almost every aspect of education. The learning process can occur well if the learning methods and techniques involve students. Selfinvolvement (learner ego) is the key to success in adult learning. Referring to Knowles [17], there are four main assumptions of the concept of andragogy, namely the selfconcept that places participants as subjects, a function of experience, learning readiness, and learning orientation. Participant-centered learning is essentially the latest version of the discovery method. Rogers argues that there are three elements that are important in experimental learning, namely:

- Participants should be faced with the real problems that they want to find solutions to.

- When the awareness of the problem has been formed, an attitude towards the problem is formed.

- The existence of learning resources, both human and written or printed materials.

Carl Rogers' experiential learning theory contains high personal, intellectual and affective engagement values, based on self-initiative. The role of the facilitator in experienced learning is simply to help participants learn to find learning needs that are meaningful to them

The suitability of the andragogical learning model can be seen from the results / outputs of participants both in terms of changes in knowledge and attitudes as well as from participant satisfaction surveys as shown by the research results of Zulbetti [12] and Siswati [11].

3) After training evaluation: At the end of the training process, participants evaluate the entire training activities both trainers, materials, facilities and fill out the post-test (final assessment) to determine their level of knowledge and understanding. At the closing session, a summary of the main learning points of the training activity is presented as a whole and matched whether the objectives and expectations of the participants conveyed at the beginning of the training had been achieved or not. Meanwhile, after the training is completed, the trainer must make an activity report in a predetermined 
format by uploading it to the MEDS system and sending a hard copy to the YEP Project / ICEFE office.

\section{E. Output}

In terms of quantity, the number of participants who have attended the FLS training is presented in the Table 2 below.

TABLE II. NUMBER OF TRAININGS, ORGANIZING INSTITUTIONS AND NUMBER OF FLS TRAINING PARTICIPANTS (JULI, 2020)

\begin{tabular}{|l|c|c|c|}
\hline \multicolumn{1}{|c|}{ Training Activities } & $\begin{array}{c}\text { Total } \\
\text { Training }\end{array}$ & $\begin{array}{c}\text { Number of } \\
\text { Institutions }\end{array}$ & $\begin{array}{c}\text { Number of } \\
\text { participants }\end{array}$ \\
\hline $\begin{array}{l}\text { Training of Youth Regular } \\
\text { Program }\end{array}$ & 86 & 36 & 1703 \\
\hline Training of Youth Modular & 25 & 6 & 476 \\
\hline $\begin{array}{l}\text { Training of Youth Non- } \\
\text { Regular }\end{array}$ & 17 & 13 & 4207 \\
\hline $\begin{array}{l}\text { Training of Youth with } \\
\text { Special Ability }\end{array}$ & 5 & 3 & 63 \\
\hline
\end{tabular}

In terms of the achievement of learning outcomes, it can be seen that there have been significant changes between before and after the training [11] and as many as 95\% of the participants in the ToY at Paksi Ganesha expressed satisfaction with the training process [12]. This is in line with the participant's testimonials published on social media.

ToY participants will receive an electronic certificate from YEP - USAID.

\section{CONCLUSION}

Based on the results of the study, the FLS training program has been designed in accordance with the four pillars of education and has been developed in accordance with the principles of non-formal education, namely the principle of need, the principle of relevance, the principle of future insight and the principle of lifelong education.

Standardized training for trainers makes FLS trainers have sufficient capabilities to facilitate training properly.

Comprehensive curriculum and modules, along with a wellmanaged training process and IT system support for monitoring and evaluating produced the well-developed FLS training which is able to achieve the goals.

Learning evaluation in FLS training is implemented before, during and after the training takes place. Learning process applies an andragogy system that makes participants directly involved in learning. A curriculum that combines financial literacy with life skills makes learning more meaningful.

\section{REFERENCES}

[1] Otoritas Jasa Keuangan, Laporan Tahunan. Jakarta: OJK, 2019.

[2] M.H. McCormick, "The effectiveness of youth financial education: A review of the literature," Journal of Financial Counseling and Planning, vol. 20, no. 1, 2009

[3] Organisation for Economic Co-operation and Development, OECD skills outlook 2013: First results from the survey of adult skills. Paris: OECD Publishing, 2013.

[4] A. Lusardi, "Financial literacy: an essential tool for informed consumer choice?", National Bureau of Economic Research Working Paper Series No. 14084, 2008

[5] J.D. Cummins, G. Dionne, R. Gagné, and A.H. Nouira, "Efficiency of insurance firms with endogenous risk management and financial intermediation activities," Journal of Productivity Analysis, vol. 32, pp. 145-159, 2009

[6] V.G. Perry and M.D. Morris, "Who is in control? The role of self-perception, knowledge, and income in explaining consumer financial behavior," Journal of consumer affairs, vol. 39, pp. 299-313, 2005 .

[7] F. Carpena, S.A. Cole, J. Shapiro and B. Zia, Unpacking the causal chain of financial literacy. World Bank Policy Research Working Paper, 2011 .

[8] L. Mandell and L. Klein, "The Impact Of Financial Literacy Education On Subsequent Financial Behavior." Journal of Financial Counseling and Planning, vol. 20, pp. 15-25, 2009.

[9] A. Prawitz and J. Cohart, "Workplace Financial Education Facilitates Improvement In Personal Financial Behaviors," Journal of Financial Counseling and Planning, vol. 25, 2014.

[10] T.A. Lucey, M.F. Agnello, and J.D. Laney, A critically compassionate approach to financial literacy. Springer, 2015.

[11] A. Siswati, "Experiental Learning Pelatihan Financial Life Skills Pada Mahasiswa Universitas Merdeka Malang," Jurnal Bisnis dan Manajemen, vol. 6, pp. 81-87, 2019.

[12] R. Zulbetti, P. Perwito, and Y. Ratna, "Pelatihan Financial Life Skills (FLS) Untuk Membangun Kemandirian Pemuda Taruna Politeknik Piksi Ganesha," Prosiding Sembadha, vol. 1, pp. 144-150, 2018.

[13] R.W. Tyler, "Basic principles of curriculum development. Chicago: University of Chicago Press," Performance Improvement Quarterly, vol. 3, pp. 65-70, 1950.

[14] B.S. Bloom, Handbook on formative and summative evaluation of student learning. ERIC, 1971.

[15] S. Suryabrata, Pengukuran dan penilaian pendidikan. Dirjen Pendidikan, 1981.

[16] D. Sudjana, Evaluasi Program Pendidikan Luar Sekolah: Untuk Pendidikan Nonformal dan Pengembangan Sumber Daya Manusia. Bandung: Remaja Rosdakarya, 2006, pp. 34-46.

[17] M.S. Knowles, Andragogy. NETCHE, 1972. 